\title{
BORROWED CAPITAL IN COMPANIES OPERATING IN BRANCH PURCHASING GROUPS
}

\begin{abstract}
The aim of this article was to present a foreign policy of capital management in commercial companies operating in the branch purchasing groups. In the article a detailed characteristics and classification of borrowed capital was done. Borrowed capitals were divided into short-term liabilities, long-term liabilities and provisions for liabilities. The advantages and disadvantages of various external sources of financing were presented. Then selected indicators to evaluate capital management policy in selected companies were presented. In the study the indicators showing the structure of borrowed capitals and selected measures of financial analysis were applied. These were debt, liquidity and turnover ratios. The study was conducted on a group of 17 small and medium-sized units in the construction industry. The companies tested belonged to the branch purchasing group. The period of study concerned the year 2104 . The study showed that in the majority of the companies involved the share of borrowed capitals in liabilities was little. A clear advantage have the equities. In the structure of borrowed capital a clear predominance have short-term liabilities and shortterm loans. In more than half of companies long-term liabilities do not exist, and several other companies are a negligible part in relation to the total liabilities. The highest share in current liabilities are liabilities to suppliers, which is the cheapest source of financing. The studies have shown that in the analyzed units there is no threat of the loss of liquidity. This is the result of the application of good and safe management policy of external sources of companies financing.
\end{abstract} groups

Keywords: management, borrowed capital, liabilities, financial indicators, purchasing

\section{INTRODUCTION}

Management of company financial sources has a huge impact on the financial results of companies and their safe operation. The choice of the right policy to control the individual sources of financing and the development of an appropriate structure depends on the direction in which business is conducted. Managers have to choose a safe direction characterized by high liquidity and low profitability or an aggressive direction aimed at high profit and low levels of liquidity. The problem with the management of financial sources of businesses is connected with an adjustment of the appropriate level and structure of the own and foreign equities. One needs to remember that capital as other factors of production has its price ${ }^{2}$. When selecting the appropriate sources of financing one should take into account criteria such as availability, cost, flexibility, financial leverage effect and risk operation ${ }^{3}$. Thus, it is a complex process and mistakes made in this man-

\footnotetext{
${ }^{1}$ Dr inż. Grzegorz Zimon, Zakład Finansów, Bankowości i Rachunkowości, Politechnika Rzeszowska, Wydział Zarządzania, al. Powstańców Warszawy 10, 35-959 Rzeszów, tel.: 17865 16 33, e-mail: gzimon@ prz.edu.pl,

${ }^{2}$ P. Karpuś, Zarządzanie finansami przedsiębiorstw, Wydawnictwo UMCS, Lublin 2006, p. 213.

${ }^{3}$ A. Rutkowski, Zarządzanie finansami, Polskie Wydawnictwo Ekonomiczne, Warszawa 2007, p. 271.
} 
agement area will adversely affect the financial results of companies and financial liquidity. In the case of the selection of financing sources, managers have to pay special attention to the level of borrowed capital in the unit as it has a great impact on the liquidity level. Despite this danger, the use of this type of financing is beneficial for businesses because very often it is the cheapest source of financing assets. In the article a management analysis of the borrowed capital operating in the branch purchasing groups was done.

\section{SOURCES OF COMPANIES FINANCING}

Liabilities are the sources of financing the assets of businesses. In a company the sources of assets financing can be different: part of it is financed from their own sources, others from external sources. Own sources of funding are called own capitals (funds) and foreign sources are capitals (funds) or foreign liabilities ${ }^{4}$. They can be divided into two groups due to the way in which they are obtained, i.e. internal and external ${ }^{5}$. External capital means that the company raises funds to finance assets from outside of the company. Internal capital is the one that comes from the company profit. A detailed division is shown in figure 1 below.

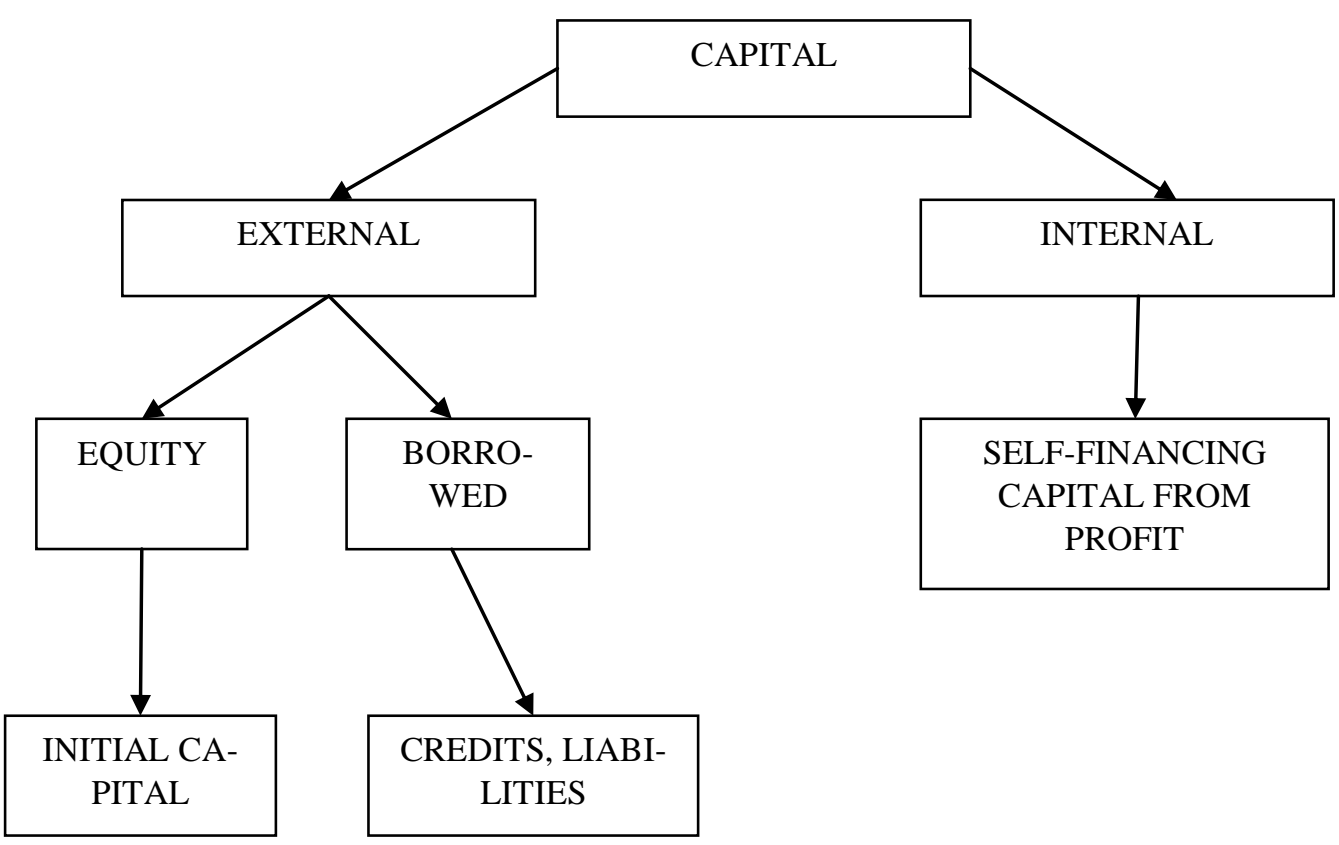

Fig. 1 Capitals division according to sources of origin Source: own research

\footnotetext{
${ }^{4}$ E. Nowak, Analiza sprawozdań finansowych, PWE, Warszawa 2005, p. 82.

${ }^{5}$ A. Rutkowski, Zarządzanie finansami, Polskie Wydawnictwo Ekonomiczne, Warszawa 2007, p. 273.
} 
Another division from the point of view of maturity of financial instruments, which are used to raise capital, is the one into long-term and short-term sources of assets financing ${ }^{6}$.

Equity capital is created from shareholders' contributions, the contribution of the owners or partners of the company, but the contribution may take the form of cash or non-cash contribution as assets in kind ${ }^{7}$. This type of financing should be identified as safe and it ensures a stable level of asset financing. The high level of equity capitals has a beneficial effect on the liquidity of companies as it limits liability. The equity capital along with long-term liabilities is determined as the constant capital (long-term), while short-term liabilities are short-term capitals ${ }^{8}$.

Borrowed capital are funds available to the companies for a specific period with the relevant remuneration whose amount is determined in the agreement between the parties, taking into account the overall market relations ${ }^{9}$. In the group of borrowed capital there are reserves that a company creates for future liabilities relating to deferred income tax, pensions and other company guarantees, warranties or a pending court proceedings. Thus, the borrowed capitals can be divided according to the criteria for punctuality and reliability ${ }^{10}$.

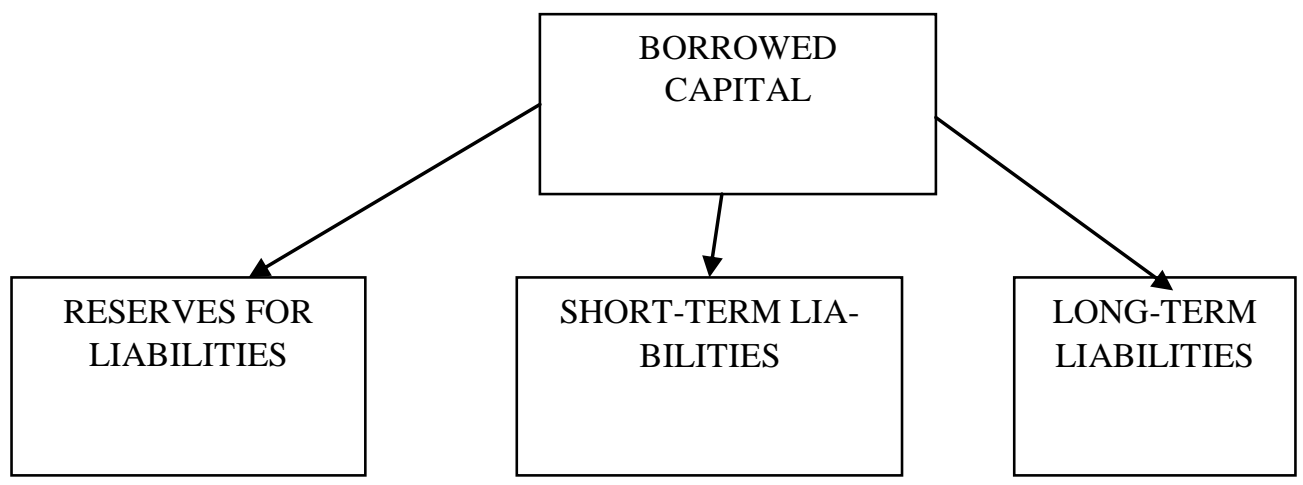

Fig. 2. The division of borrowed capitals Source: own research

\footnotetext{
${ }^{6}$ P. Karpuś, Zarządzanie finansami przedsiębiorstw, Wydawnictwo UMCS, Lublin 2006, p. 270.

${ }^{7}$ E. Nowak, Analiza sprawozdań finansowych, PWE, Warszawa 2005, p.80.

${ }^{8}$ W. Dębski, Teoretyczne i praktyczne aspekty zarzadzania finansami przedsiębiorstwa, PWN, Warszawa 2005, p. 272.

${ }^{9}$ W. Szczęsny, Finanse. Zarys wyktadu, Difin, Warszawa 2010, p. 279.

${ }^{10}$ W. Gabrusewicz, Analiza finansowa przedsiębiorstw. Teoria i praktyka, PWE, Warszawa 2014, p. 162.
} 
Liabilities are a borrowed capital. The scope of the commitments includes: ${ }^{11}$

1. Long-term liabilities, mostly for credits, loans, issuing of own debt securities - which the part or all of them will be due 12 months after the balance sheet date.

2. Short-term liabilities for:

- Loans and credits, whose payments will be due and payable within one year from the date of the balance sheet,

- Supplies,

- Remuneration,

- Taxes, duties, social insurances,

- Issued bills,

- Other liabilities

Short-term financing sources are those obligations whose payment deadline expires within one year from the moment of their creation. They can be divided into two groups ${ }^{12}$ :

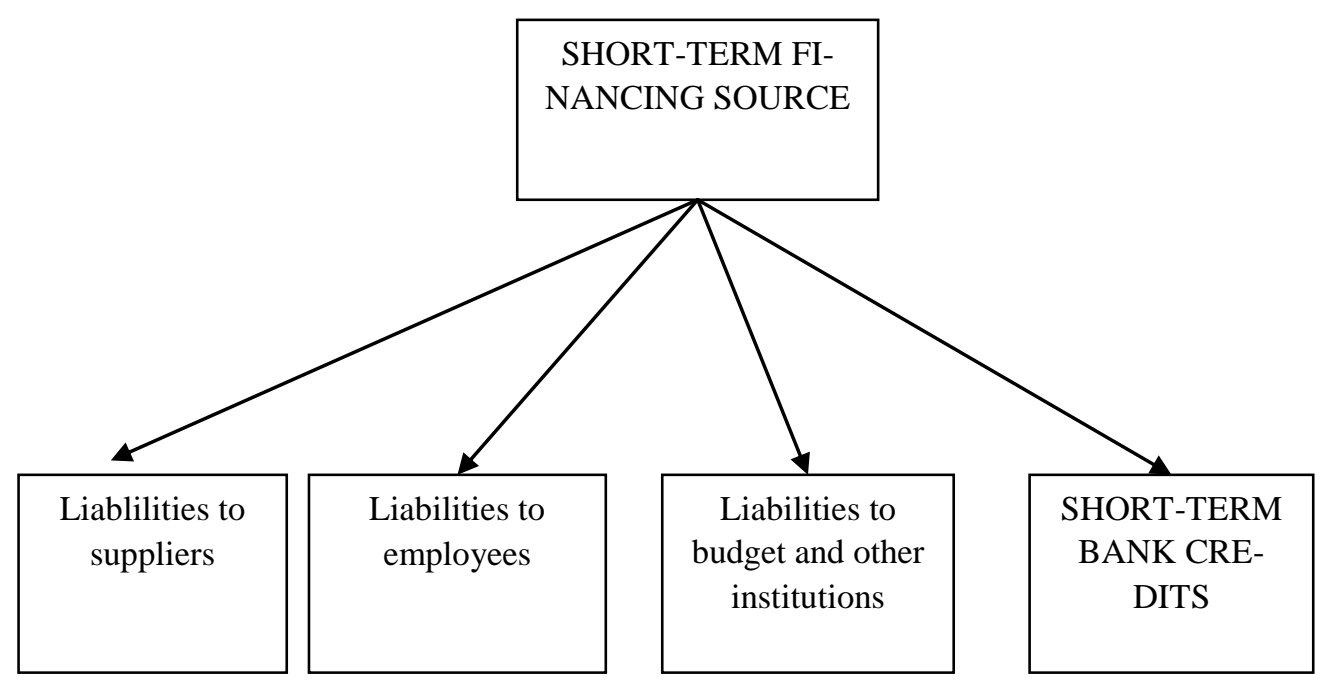

Fig. 3. The division of short-term financing sources

Source: own research Another division, which needs to be applied in the case of borrowed capital, is to divide the liabilities into interest and non-interest ones. This is an important criterion and should be critical about the order of payment of current and overdue liabilities. The largest share of current liabilities of a non-financial corporation are liabilities to suppliers of about $40 \%{ }^{13}$.

\footnotetext{
${ }^{11}$ W. Gos, S. Hońko, P. Szczypa, ABC Sprawozdań finansowych. Jak je czytać, interpretować i analizować, CEDEWU, Warszawa 2013, p. 127.

${ }^{12} \mathrm{~W}$. Dębski, Teoretyczne i praktyczne aspekty zarządzania finansami przedsiębiorstwa, PWN, Warszawa 2005, p. 279.

${ }^{13}$ E.F. Bringham, J.F. Houston, Podstawy zarzadzania finansami, PWE, Warszawa 2005, p. 278.
} 
Borrowed capital is very important for businesses because very often it is the cheapest source of financing such assets, e.g. liabilities to suppliers. However, in case of no control, its level can be very expensive e.g. penalty interest, installment credit. Its too high level has a negative impact on the security of the company, i.e. its liquidity. Its level must, therefore, be systematically controlled.

\section{INDICATORS TO ASSESS BORROWED CAPITAL MANAGEMENT}

When analyzing the level of borrowed capital in a company one should use the financial analysis of financial statements. The first indicator is the level of equity in relation to the liabilities.

$$
\text { Indicator of capital structure }=\frac{\text { equity capital }}{\text { borrowed capital }}
$$

The higher the level, the more preferably one should assess the financial situation of the company and its growth opportunities ${ }^{14}$. Another indicator concerning borrowed capital and based on the levels of the related balance sheet items is an indicator of the use of borrowed capital.

$$
\text { Indicator of borrowed capital use } \frac{\text { equity capital }}{\text { assets }}
$$

These measures indicate the extent to which the individual capitals finance the assets. If the above ratio is equal to unity, then it is met the minimum requirement of the golden balance rule in relation to the assets ${ }^{15}$. For the company it is beneficial when this ratio is less than unity. This means financing assets by the constant capital. The company in this case has a positive working capital, which has a positive effect on the level of financial liquidity.

Another indicator to inform whether borrowed capitals do not reach too high levels in the company is an indicator of liquidity. Its result should be above 1 . In general, the literature teaches that it should be in the range of 1.2-1.8. This indicator already higher than 2 informs about liquidity excess, which means unnecessary costs for the company.

$$
\text { Financial liquidity indicator } \frac{\text { assets }}{\text { short }- \text { term liabilities }}
$$

\footnotetext{
${ }^{14}$ L. Bednarski, Analiza finansowa w przedsiębiorstwie, PWE, Warszawa 2007, p. 78.

${ }^{15}$ W. Gabrusewicz, op. cit., p. 162.
} 
Subsequent indicators, which in more detail describe the involvement of various borrowed capitals, are indicators of the share of short and long-term liabilities in total liabilities.

Long - term liabilities share indicator $\frac{\text { long - term liabilities }}{\text { total liabilities }}$

Short - term liabilities share indicator $\frac{\text { short }- \text { term liabilities }}{\text { total liabilities }}$

The higher the level reaches the share rate of long-term liabilities, the more stable and secure is the situation of the company. In turn, the high share of the share rate of shortterm liabilities in total liabilities informs about the low liquidity of the company.

Another indicator informs about the speed of liabilities turnover in days. It is a cycle of liabilities conversion.

Cycle of short - term liabilities $\frac{\text { short }- \text { term liabilities }}{\text { incomes from sales }} x 365$ days

This indicator defines the average time to postpone the payment of liabilities and the scope of use of interest-free capital by deferring payments and postponing the outflow of money from the company ${ }^{16}$. It is a very good measure to assess a counterparty that the company will trade in the future.

\section{MANAGEMENT ANALYSIS OF BORROWED CAPITAL}

The purpose of the analysis of capital resources is to determine what the structure of asset financing is and whether it can be improved. It is, therefore, to assess if the company has an adequate capital, i.e. to determine what types of capital is used by the company, to assess the financing range of equity and borrowed capital ${ }^{17}$. The study was conducted on a purchasing group of 17 commercial SMEs from the construction branch (table 1).

The period of study concerned the year 2104. The surveyed companies operate in the branch purchasing group. The purchasing groups is a group of co-operating companies on many levels, managed by a specially created central unit. The aim of the unit is the realization of tasks commissioned by the companies making up the purchasing group. The execution of these tasks is to ensure better financial performance, competitive advantage and safety for companies creating the purchasing group. Acting under the common name

\footnotetext{
${ }^{16}$ M. Sierpińska, D. Wędzki, Zarządzanie plynnościa finansowa w przedsiębiorstwie, PWN, Warszawa 2005, p. 249.

${ }^{17}$ W. Gabrusewicz, op. cit., p. 131.
} 
it is formed today, among other things, a coherent strategy for the development of enterprises, unified marketing, a new brand, joint sales and logistics ${ }^{18}$. Purchasing groups can be divided into branch and multi-branch. Functioning within multi-branch groups increases the economies of scale, i.e. the most important factor in building a competitive advantage

Table 1. Selected indicators for assessment of the borrowed capital management

\begin{tabular}{|c|c|c|c|c|c|c|c|}
\hline $\begin{array}{l}\text { Indica- } \\
\text { tor/company }\end{array}$ & $\begin{array}{l}\text { Borro- } \\
\text { wed } \\
\text { capi- } \\
\text { tal/total } \\
\text { assets }\end{array}$ & $\begin{array}{l}\text { Long- } \\
\text { term } \\
\text { liabili- } \\
\text { ties/Total } \\
\text { liabilities }\end{array}$ & $\begin{array}{l}\text { Short- } \\
\text { term } \\
\text { liabili- } \\
\text { ties/Total } \\
\text { liabilities }\end{array}$ & $\begin{array}{l}\text { Conver- } \\
\text { sion } \\
\text { cycle of } \\
\text { short- } \\
\text { term } \\
\text { liabili- } \\
\text { ties }\end{array}$ & $\begin{array}{l}\text { Cur- } \\
\text { rent } \\
\text { finan- } \\
\text { cial } \\
\text { liqu- } \\
\text { idity }\end{array}$ & $\begin{array}{l}\text { Liabili- } \\
\text { ties to } \\
\text { suppli- } \\
\text { ers/ } \\
\text { /short- } \\
\text { term } \\
\text { liabilities }\end{array}$ & $\begin{array}{l}\text { Short- } \\
\text { term } \\
\text { cred- } \\
\text { its/short- } \\
\text { term } \\
\text { liabilities }\end{array}$ \\
\hline Company 1 & 0,36 & 0,23 & 0,77 & 98 & 1,95 & 0,35 & 0,53 \\
\hline Company 2 & 0,09 & 0 & 1 & 24 & 9,1 & 0,61 & 0,0 \\
\hline Company 3 & 0,73 & 0,07 & 0,93 & 109 & 1,25 & 0,5 & $0,, 44$ \\
\hline Company 4 & 0,3 & 0 & 1 & 46 & 3,1 & 0,7 & 0,14 \\
\hline Company 5 & 0,34 & 0,05 & 0,95 & 113 & 1,47 & 0,63 & 0,16 \\
\hline Company 6 & 0,68 & 0,77 & 0,23 & 27 & 6,1 & 0,82 & 0 \\
\hline Company 7 & 0,49 & 0,08 & 0,92 & 57 & 2,1 & 0,40 & 0,55 \\
\hline Company 8 & 0,04 & 0 & 1 & 14 & 12 & 0,55 & 0 \\
\hline Company 9 & 0,21 & 0,04 & 0,96 & 22 & 4,6 & 0,34 & 0,43 \\
\hline Company 10 & 0,15 & 0,13 & 0,87 & 20 & 7,1 & 0,49 & 0 \\
\hline Company 11 & 0,61 & 0 & 1 & 79 & 1,47 & 0,54 & 0,36 \\
\hline Company 12 & 0,1 & 0 & 1 & 21 & 10,2 & 0,56 & 0 \\
\hline Company 13 & 0,63 & 0 & 0,99 & 103 & 1,3 & 0,4 & 0,41 \\
\hline Company 14 & 0,08 & 0 & 0,99 & 15 & 9,5 & 0,4 & 0 \\
\hline Company 15 & 0,65 & 0 & 1 & 97 & 1,5 & 0,32 & 0,2 \\
\hline Company 16 & 0,79 & 0 & 1 & 83 & 1,2 & 0,64 & 0,31 \\
\hline Company 17 & 0,55 & 0,1 & 0,9 & 118 & 1,3 & 0,54 & 0,32 \\
\hline
\end{tabular}

Source: own research based upon financial statements of the companies surveyed

18 G. Zimon, Plynność finansowa w przedsiębiorstwach tworzacych grupy zakupowe, [in:] Zarządzanie finansami firm- teoria i praktyka, ed. A. Kopiński, P. Kowalik, Prace Naukowe Uniwersytetu Ekonomicznego we Wrocławiu 321, Wrocław 2013, p. 213. 
The first indicator, which was used for the analysis, is the overall debt indicator. It is most commonly used indicator informing of the level of debt. It is defined as the dependency ratio of assets liabilities ${ }^{19}$. A high score of this index indicates a high dependence of the company of the borrowed capital. This is an unfavorable situation. Low score indicates financial independence as the assets are largely financed with equity. The optimal level of this ratio is in a limit from 0,57 to $0,67 .^{20}$ Studies have shown that 6 of the 17 companies achieve optimal results. The remaining 10 companies show low levels of the borrowed capital in financing assets. The companies surveyed benefit from the borrowed capital not often, usually it represents $30 \%$ of total liabilities. Only in one case we can see a high level of the borrowed capital in the structure of liabilities, of about $80 \%$.

Analyzing the structure of liabilities one should pay attention to the fact that the structure of liabilities is considered to be favorable when the share of long-term debt is higher than the share of short-term liabilities in total liabilities. Short-term liabilities are faster due and must be repaid in the short term ${ }^{21}$. The term of payment of long-term liabilities is longer. Thus, companies have time to settle obligations. The studies have found only one case when long-term liabilities have an advantage over short-term ones. In the other 15 companies the reached level was of about $15 \%$. Companies mainly use short-term commitment, which requires close monitoring and analysis of current liabilities. Such a high share of short-term liabilities ha a negative impact on the level of liquidity.

Another indicator is a series of conversion obligations or the information after which time the company pays its obligations. In the case of 9 companies the result for this indicator is a period of 60 days. The remaining eight companies received more than 80 days, and most of them about 100 days. This result indicates that for a long period of time the company benefits from the cheapest sources of financing, which are trade credits. A big impact has the strength of a purchasing group or economies of scale. Companies order goods together and achieve long term for the settlement of liabilities.

The high share of short-term liabilities has a negative impact on financial liquidity ratio. However, more than in a half, which is 9 companies this ratio reaches more than 2,0. In the remaining companies it is above 1,2. All surveyed companies have the ability to settle their current liabilities.

When analysing the ratios of the structure of liabilities it was observed an advantage of liabilities to suppliers over loans. This is a favorable situation for the company when there are more non-interest liabilities. Credit liabilities are interest, commissions, this type of commitment is best used as a last resort. In addition, growing loans, interest limit, in case of emergency, the possibility of receiving the following additional loans.

\section{CONCLUSIONS}

In the majority of the companies involved the share of borrowed capital in liabilities is low. Own equities have a clear advantage. In the structure of borrowed capital a clear predominance of short-term liabilities is visible. In more than half, as in the 9 companies long-term liabilities do not exist, and in several other companies they even do not account for $10 \%$ of total liabilities. The highest share in current liabilities are liabilities to suppli-

\footnotetext{
${ }^{19}$ E. Nowak, Analiza sprawozdań finansowych, PWE, Warszawa 2005, p. 222.

${ }^{20}$ W. Gabrusewicz, Podstawy analizy finansowej, PWE, Warszawa 2005, p. 221.

${ }^{21}$ E. Nowak, Analiza sprawozdań finansowych, PWE, Warszawa 2005, p. 224.
} 
ers, which is the cheapest source of financing. In the surveyed companies the repayment commitments is long. Despite the high level of short-term liabilities in the surveyed companies, in most cases there is no danger of losing financial liquidity. In many organizations, financial liquidity ratio of more than 2. The surveyed companies implement safe management policy of borrowed capital as evidenced by the low level of short-term liabilities

\section{REFERENCES}

[1] Bednarski L., Analiza finansowa w przedsiębiorstwie, PWE, Warszawa 2007.

[2] Brigham E.F., Houston J.F., Podstawy zarzadzania finansami, PWE, Warszawa 2005.

[3] Dębski W., Teoretyczne i praktyczne aspekty zarządzania finansami przedsiębiorstwa, PWN, Warszawa 2005.

[4] Gabrusewicz W., Podstawy analizy finansowej, PWE, Warszawa 2005.

[5] Gos W., Hońko S., Szczypa P., ABC Sprawozdań finansowych. Jak je czytać, interpretować $i$ analizować, CDEWU, Warszawa 2013.

[6] Karpuś P., Zarządzanie finansami przedsiębiorstw, Wydawnictwo UMCS, Lublin 2006.

[7] Nowak E., Analiza sprawozdań finansowych, PWE, Warszawa 2005.

[8] Rutkowski A., Zarzadzanie finansami, PWE Warszawa 2007.

[9] Sierpińska M., Wędzki D., Zarządzanie płynnościa finansowa w przedsiębiorstwie, PWN, Warszawa 2005

[10] Szczęsny W. Finanse. Zarys wyktadu, Difin, Warszawa 2010.

[11] Zimon G., Ptynność finansowa w przedsiębiorstwach tworzacych grupy zakupowe, [in:] Zarzadzanie finansami firm - teoria i praktyka, ed. A. Kopiński, P. Kowalik, Prace Naukowe Uniwersytetu Ekonomicznego we Wrocławiu 321, Wrocław 2013.

\section{KAPITAŁ OBCY W PRZEDSIEBIORSTWACH HANDLOWYCH DZIALAJĄCYCH W BRANŻOWYCH GRUPACH ZAKUPOWYCH}

Celem artykułu było przedstawienie polityki zarządzania kapitałem obcym w przedsiębiorstwach handlowych działających w branżowych grupach zakupowych. W artykule dokonano szczegółowej charakterystyki i klasyfikacji kapitałów obcych. Zostały one podzielone na zobowiązania krótkoterminowe, zobowiązania długoterminowe oraz rezerwy na zobowiązania. Przedstawiono zalety i wady poszczególnych obcych źródeł finansowania. Następnie zaprezentowano wybrane wskaźniki służące ocenie polityki zarządzania kapitałem w wybranych przedsiębiorstwach. Do badań wykorzystano wskaźniki ilustrujące strukturę kapitałów obcych oraz wybrane mierniki analizy finansowej. Były to wskaźniki zadłużenia, płynności finansowej i rotacji. Badania zostały przeprowadzone na grupie 17 małych i średnich jednostek z branży budowlanej. Firmy poddane badaniom działały w branżowej grupie zakupowej. Okres badań dotyczył roku 2014. Przeprowadzone badania wykazały, że w większości badanych firm udział kapitałów obcych w pasywach jest niewielki. Wyraźną przewagę mają kapitały własne. W strukturze kapitałów obcych wyraźna jest przewaga zobowiązań krótkoterminowych i kredytów krótkoterminowych. W ponad połowie przedsiębiorstwach zobowiązania długoterminowe nie występują, a w kilku pozostałych przedsiębiorstwach stanowią śladowy udział w stosunku do zobowiązań ogółem. Najwyższy udział w zobowiązaniach krótkoterminowych stanowią zobowiązania wobec dostawców, czyli najtańsze źródło finansowania. Badania wykazały, że obecnie w przeanalizowanych jednostkach nie występują zagrożenia dotyczące utraty płynności finansowej. Jest to wynik stosowania dobrej, bezpiecznej polityki zarządzania obcymi źródłami finansowania firm. 
Słowa kluczowe: zarządzanie, kapitał obcy, zobowiązania, wskaźniki finansowe, grupy zakupowe

DOI: 10.7862/rz.2016.mmr.24

Tekst złożono w redakcji: kwiecień 2016

Przyjęto do druku: wrzesień 2016 